\title{
Expressions of commitment and independence: Exploring men's emotional responsibility in heterosexual couple relationships
}

\section{Tove Thagaard}

Department for sociology and human geography

University of Oslo

Email: tove.thagaard@sosgeo.uio.no

\section{Kari Stefansen}

Norwegian Social Research

Oslo and Akershus University College of Applied Sciences

Email: kari.stefansen@nova.hioa.no

\begin{abstract}
This paper examines men's contributions to the division of emotional labour in heterosexual couple relationships by exploring the dimensions of commitment and independence, and how couples deal with challenges. The study is based on individual interviews with each of the partners in ten urban middle-class couples in Norway. The results indicate diversity in middle-class men's approaches to emotional responsibility, which is expressed through three models. The model of shared responsibility implies that the man's contributions in the relationship represent expressions of responsive commitment. The man finds a balance between giving priority to his personal interests and considering shared interests; a pattern we refer to as collaborative independence, and he shares the responsibility for coping with challenges with his partner. The model of gendered responsibility implies that the man's contributions in the relationship are characterized by nonresponsive commitment. The man gives priority to his personal interests in a way we refer to as conflicting independence, and refrains from sharing the responsibility for coping with challenges with his partner. Finally, a third model, termed partial responsibility, is also evident in the data. This model is a combination of collaborative independence and non-responsive commitment,
\end{abstract}


and may represent a phase of transition towards collaboration on an equal basis. A discussion of interpretations of the diversity in men's approaches to commitment and independence concludes the paper.

Keywords: heterosexual couple relationships, men, commitment, independence, emotional responsibility, love, gender

\section{Introduction}

The aim of this paper is to explore men's emotional contributions in heterosexual couple relationships. Previous research on the emotional dimension of conjugal relationships has focused primarily on women's emotional investments - and men's lack thereof: studies have demonstrated that women shoulder the main responsibility for intimacy and commitment in couple relationships (Illouz, 1997; Duncombe \& Marsden, 1999; Jamieson, 1999; Magnusson, 2006). Compared with men, women tend to invest more in their relationships and to pay more attention to the well-being of their partners (Strazdins \& Broom, 2004; Holmes, 2004; Kimmel, 2004; Rauer \& Volling, 2005; Thagaard, 2005).

This research tradition departs from a feminist perspective in which the traditional relationship structure places the man in a dominant position with the woman relatively subordinate (Jónasdottir, 1991; Haavind, 2000). Jamieson (1999) for instance views the structurally based gender inequality as a bottom layer in modern love relationships. The man's dominant position implies that he can prioritize his own interests at the expense of the couple's common sphere, in a way the woman cannot (Holmberg, 1995), and the feminist perspective associates the man's position with autonomy and independence (Seidler, 1998; Demsey, 2002; Kimmel, 2004).

While this perspective sheds light on how gender relations are reproduced through women's emotional work, we believe it is less suitable for the study of men's emotional contributions in heterosexual couple relationships (see Aarseth, 2008). What is needed is an approach that can capture both old and new patterns in the emotional division of labour. Our approach is inspired by Connell and Messerschmidt (2005), who emphasize how changes in conceptions of hegemonic masculinities are related to new gender roles in couple relationships, as seen, for instance, in the companionate marriage.

This paper analyses the emotional contributions of men in lasting couple relationships by exploring how they express both commitment and independence. These are key dimensions in couple relationships, and we shall analyse how they combine in distinct models of male emotional 
responsibility. The concepts of commitment and independence capture, respectively, emotional involvement and differentiation in couple relationships. These concepts have gendered connotations; commitment is associated with the view of women as love experts (Kimmel, 2004), while independence is associated with the view that men prioritize their own interests (Røthing, 2004).

We explore men's expressions of commitment by focusing on the types of expressions that both partners in each couple see as contributing to their relationship. Following this analysis, we explore expressions of independence, defined as the priority of 'a time of one's own'. Finally, we analyse the interrelationships between men's expressions of commitment and independence and their responses to challenges and tensions in their couple relationships.

The analysis is based on qualitative interviews with both partners from ten Norwegian middle-class couples. It should be noted that the Nordic countries, including Norway, are 'characterized by an exceptionally strong political emphasis on equality between women and men as national goals, compared to most other countries in the world' (Magnusson, 2008, p. 81). Family-policy scholars also commonly point to the Nordic countries as having the most pronounced policies for advancing fathers' share of care work and gender equality (Gornick \& Meyers, 2009; Lister, 2009; Ellingsæter, 2011). Thus, the Nordic region makes a particularly interesting case for the study of men's new roles in couple relationships.

\section{Theoretical perspectives}

\section{Commitment}

In The Transformation of Intimacy, Giddens (1992) identifies a particular relational dynamic in couple relationships: the pure relationship. This is a relational dynamic based on reciprocity and a mutual disclosing of the self. Intimacy in this sense is incompatible with the traditional gendered pattern of heterosexual love, i.e. relationships in which the woman is responsible for maintaining the emotional bond (Jamieson, 1999). The dimension of intimacy that is foregrounded here is a disclosing intimacy, 'a process of ... mutually sustaining deep knowing and understanding, through talk and listening, sharing thoughts, showing feelings' (Jamieson, 1998, p. 158).

Analytically this dimension of intimacy may be distinguished from what Jamieson (1998, p. 8) designates silent intimacy, i.e. an intimacy of doing and being rather than talking. 'For couples who live together, the time, money and effort each devotes to the household often symbolizes love and care for the 
other' (Jamieson, 1999, p. 485). Cancian (1986) argues that women are considered more loving than men because men's behaviour is measured with a feminine ruler. She writes: 'Much of this research considers only the kinds of loving behaviour that are associated with the feminine role and rarely compares women and men in terms of qualities associated with the masculine role' (p. 701). According to Kimmel (2004) men's contributions in close relationships are often instrumental and task-oriented. Thus, an exploration of men's emotional contributions in couple relationships must consider the roles of both direct, verbalized and indirect, task-oriented expressions of commitment. As Kimmel has pointed out, one of the consequences of the dominant, feminized notion of love is that expressions of love perceived as feminine, such as talking about feelings, are given priority over practical aspects of the relationship, such as helping one's partner with different sorts of tasks.

Following the lead of Jamieson, Cancian and Kimmel, we see intimacy as multi-dimensional. Regarding changes in men's emotional contributions in lasting relationships, we believe that it is important to consider 'acts of practical love and care' (Jamieson, 1999, p. 477) in addition to practices indicative of disclosing intimacy. Our analysis, then, focuses on men's communicative and task-oriented contributions in couple relationships. We see these contributions as expressions of commitment; such acts communicate the man's commitment towards maintaining an emotionally close relationship with his partner.

Our analysis also utilizes Asplund's (1987) notion of social responsivity, which draws attention to the importance of feedback processes in social interactions. Social responsivity implies that what one person does, or the words he or she uses, represents a reaction to what the other person has done or said. Asplund associates social responsivity with the immediacy and spontaneity of reactions in interactions. A lack of response by one individual to the other is designated asocial responselessness.

Descriptions of spontaneity in social interactions are represented in our data to only a limited extent. The participants described situations characterized by spontaneous reactions, but they also had more general views on the overall amount of positive feedback from their partner. With Asplund's perspective as a point of departure we apply the concept of responsivity to the exploration of expressions of commitment. In this article, however, responsivity has implications related to spontaneous reactions as well as more general descriptions of the partner's reactions. 


\section{Independence}

Independence is an important dimension in studies of men's values and positions. Kimmel (2004) emphasizes how men's independence is encouraged already in early adolescence, and Magnusson (2008) refers to couples whose repertoires of individualism imply that they consider it more self-evident for the man to prioritize work and leisure activities than it is for the woman.

It is important to consider both the abstract and concrete meanings of independence. In the abstract, independence refers to separateness, a wish to withdraw and distance oneself from other people. The expression 'a space of one's own', which we use in this paper, reflects this connotation. The concrete meaning of independence refers to the prioritization of time for personal interests. In negotiations, arguments for independence tend to be expressed as wishes for pursuing personal interests. In our analysis, the dimension of independence includes both a space of one's own and the prioritization of time for personal interests.

Beck and Beck-Gernsheim (1995) associate separate time with freedom, both to work towards self-realization and simply to be oneself. In their view, freedom for one partner represents the renunciation of freedom for the other. An interpretation of independence which accords with Beck and BeckGernsheim is that independence is a limited resource, an asset that one partner can use at the expense of the other. This is not necessarily the case: the pursuit of time for separate interests may be practised in ways that do not conflict with possibilities for shared time and that do not entail emotional distancing. Our analysis aims to capture this distinction.

\section{The study}

We conducted separate interviews with each of the partners from ten heterosexual, dual-earner couples, all of whom were in their early 30 s and living in the Oslo area. The participants were in relationships they considered to be permanent. Seven couples were married and three were unmarried but cohabiting. The concept partner is used throughout this article to refer to either the male or female partner in both married and non-married couples. At the time of the study, four of the couples had young children. In all the couples, each of the partners worked full-time in demanding jobs.

The couples belong to the urban middle class. The selection of couples in this age group from this particular segment of the population was based on the assumption that both partners would be familiar with modern expectations regarding men's emotional contributions to permanent relationships. The sample represents couples who are sharing costs and benefits equally. This 
pattern is also documented in a larger study about men's quality of life (Holter, Svare, \& Egeland, 2008). For each couple in our sample, the two partners also have approximately equal amounts of both economic resources and assets. Owing to sample size and homogeneity we do not explore variations between the couples in level of education or type of profession.

The couples were recruited through personal connections from a variety of professional settings and through snowball sampling. The interviews were semi-structured. All participants were asked questions on the same topics related to both emotional and practical aspects of the couple relationship, but the sequence and the precise wording of the questions were decided during the interview. The interviews provided rich data about both partners' experiences of emotional and practical aspects of the relationship as well as challenges they faced within the relationship.

The interviews were coded and analysed systematically. The analysis of men's responsibilities in the division of emotional labour is based on a classification of the couples according to variations in the interrelationship between commitment and independence and the men's contributions in respect of coping with challenges.

We have chosen for presentation five cases which best represent the variations in the expressions of commitment and independence. The other five cases show corresponding patterns. To ensure participants' anonymity, pseudonyms are used and further information about the case couples is not presented. It should be mentioned that there were few differences between couples with and without children.

\section{Commitment}

Commitment refers to how men communicate emotional involvement in daily interaction. We explore men's ways of communicating emotional involvement by focusing on the women's reactions to the men's contributions.

Responsive commitment implies that the woman emphasizes that the partner's contributions communicate emotional involvement. Responsive commitment may be both communicative and task-oriented, aspects referred to respectively in the following as communicative commitment and taskoriented commitment. These are not exclusive categories. Men can contribute to the relationship in both ways, but generally they are inclined to express emotional involvement through either one or the other. In couples in which the woman did not receive consideration and confirmation, the man's actions are classified as non-responsive commitment. This classification implies that the man participates in conversations or performs practical tasks, or both, but does not communicate emotional involvement. 


\section{Communicative commitment}

The case of Robert and Sara illustrates the pattern of communicative commitment. Robert and Sara both emphasize that the dialogues between them strengthen the emotional intimacy in the relationship. Their descriptions of these dialogues are captured by Jamieson's (1998) concept disclosing intimacy, which suggests that the parties involved are revealing their inner thoughts and feelings to each other.

Robert points out that he frequently expresses his feelings for Sara: 'I often tell her that I love her. I tell her as often as I can.' When he tells Sara how he feels about her, he is confirming to her that he appreciates her. Sara's reaction indicates what this means to her: 'He tells me very often that he is proud of me and fond of me. I feel very close to him then.' The way Robert discloses his feelings represents an expression of commitment.

Robert describes himself as an enthusiastic participant in the conversations he has with his partner: 'She is very engaged, and I feel very close to her then. She opens herself to me to a great degree.' Robert explains that he responds to Sara in ways that not only show his interest in what she is telling him but also reflect his feelings for her. The feedback he provides represents a basis for characterizing his contributions as responsive commitment. Sara, in turn, appreciates the sensitivity he displays in their discussions: 'I think Robert is a very considerate listener. He confirms that he appreciates me. He always pays a good deal of attention to what I am saying. This is his way of being very supportive.' The dialogues between Robert and Sara are characterized by mutual responsivity because both parties express their reactions to what the other has just said and also convey the feelings they have for one another. Both Robert and Sara describe their partner as a sensitive listener who provides considerate feedback. The communicative commitment Robert expresses indicates his emotional involvement.

The interaction between Robert and Sara is characterized by the high priority given to the quality of their communication. Over time their understanding of their respective interests and points of view has increased, and they share the opinion that good conversation is necessary for the development of the relationship. The initiative each of them takes to achieve this reflects that they share the responsibility for coping with challenges in the relationship. Sara explains how she tries to bring them back on track if the distance between them increases, and Robert explains how he has worked to be better at identifying the causes of misunderstandings and irritation. 


\section{Task-oriented commitment}

The case of John and Maria illustrates the pattern of task-oriented commitment. John explains that he has learned from newspaper and magazine articles on relationships that the way to a woman's heart is doing something for her: 'I must bear in mind that my partner is actually another person and not a part of myself. It's important to make an effort to keep the spark alive.' John's reflections indicate that he gives priority to doing things for his partner that he knows she appreciates. He explains: 'She is much more used to tidying up than I am. So when I want to please her I take a good look around and tidy up. She appreciates that.' The thoughtfulness John expresses through such practical activities forms the basis for characterizing his contributions as responsive commitment. He demonstrates that he cares for his partner, and he communicates his love by doing things for her that he knows she values. Maria appreciates what he is trying to express through his efforts:

He is good at showing that he cares; I think he is better at it than I am. He tidies up because he knows that when I come home I am going to tidy up. But he has already done it for me.

She sees his efforts as an expression of love because she understands that he does this to please her. The type of communication that characterizes interactions such as these is captured by Jamieson's (1998) concept of silent intimacy, which emphasizes how practical sharing and caring can convey love. The meaning communicated, but not explicitly spoken of, contributes to the creation of a common interpretation of these situations.

Maria's view of John's contributions as expressions of love is based on what he does beyond the tasks allotted to him in their equal sharing of household duties. John expresses consideration for her by doing something extra, things that he knows she appreciates. Hochschild's (2003) reflections on what a gift represents capture the process involved here. She writes: 'in the emotional sense on which I focus here a gift must seem extra - something beyond what we normally expect. The sense of genuine giving and receiving is a part of love' (p. 104).

John and Maria have developed an increasing understanding of the practical tasks each of them can do which the partner will see as something extra, and thus especially appreciate. The understanding of each other they have achieved implies that they also share the responsibility for coping with challenges in the relationship. John describes his role in such processes: 'Maria becomes very quiet if there is something wrong. Then I must try to find out what has happened during the last hours.' Maria appreciates that John takes the first steps towards coming up with a solution. 


\title{
Non-responsive commitment
}

The case of Victor and Kate illustrates the pattern of non-responsive commitment. Non-responsive commitment has both a communicative and a task-oriented dimension, both of which are illustrated below. Kate elaborates on the lack of response she receives in conversations with Victor:

It is difficult to talk with [Victor] about things I am interested in. Actually, I do not think that he listens very closely. He changes the subject rather quickly. Maybe he does not understand what I am trying to say? He is not even close to giving me the confirmation I am longing for.

The quotation above mirrors findings from studies that indicate a tendency for women to experience a lack of emotional participation from male partners, with the result that the women are left wanting an emotional response (Duncombe \& Marsden, 1998; Dempsey, 2002; Holmes, 2004). Strazdins and Broom's (2004) perspective captures this tendency: when women do more emotional work than men, it diminishes their sense of being loved. Men's reactions in such situations may be understood as an emotional remoteness, which falls in line with the description Seidler (1998) gives of how men learn to keep emotional needs at a distance and to suppress their emotions.

Men's task-oriented contributions are characterized as non-responsive when the woman relates that her partner is showing little consideration for her. The implication is not that the man does not do his share of the daily household duties. What the woman feels is missing are the more impulsive contributions that would indicate a deeper level of caring. As Kate describes:

\begin{abstract}
My husband is good at doing the tasks we have agreed on. But I wish that he would be more attentive and that he would understand how worn out I am at times. If only he could do something to show that he cares for me. I do not think I ask for much - but I wish that he would see and understand.
\end{abstract}

The quotation indicates that what Kate wants is for her partner to contribute in ways that demonstrate care and consideration for her, and that he would do this on his own initiative. She is asking for something extra - a gift - beyond the duties he ordinarily performs.

The interaction between Kate and Victor is characterized by disagreements and the shared feeling that they do not communicate very well. Kate tries to bring up controversial issues in order to prompt discussions that could improve the situation. The responsibility for coping with challenges rests on her. She thinks that it is important to discuss problems in the relationship before they 'explode'. Victor does not agree with her and describes himself as vague and withdrawn: 'I try to come up with some white lies in challenging situations in 
order to make things simple.' His approach seems to increase rather than to solve the problems, which he also recognizes.

\section{Independence}

Independence is explored in the context of the partners' negotiations of the organization of leisure time. In our material two different patterns emerged: conflicting independence and collaborative independence. Conflicting independence refers to situations in which the man pursues separate time in ways that entail distancing from joint activities that the woman wants. Collaborative independence refers to situations in which the man's pursuit of separate time is not regarded as a threat to the relationship or to maintaining togetherness, but rather the contrary.

The types of activities that partners are engaged in represent different types of challenges. Couples face special challenges when one partner has interests that are time-bound and time-consuming. Interests offering greater flexibility and demanding less time can more easily be adjusted to the family's everyday life. In our sample, the typical pattern is that the man has more time-bound and time-consuming interests than his female partner does.

The time-bound interests that the men in this sample engage in are, for the most part, activities with typically male connotations: outdoor sports such as hunting and fishing, watching sports on TV, and playing video games. Engaging in an activity that has masculine overtones is a way of participating in the world of men. Such participation includes both activities that men do together and pursuits that are more individualized, such as attending football matches and watching sports on TV. Parker (1996), for one, describes that sports play a role in the maintenance of masculine ideals.

\section{Conflicting independence}

The case of Peter and Jane illustrates the pattern of conflicting independence. Having time of his own is especially important to Peter. He associates personal time with 'the freedom to be on your own and do your own things' and he emphasizes the importance of pursuing his own interests. Peter's interests are activities with typically male connotations, especially sports. He explains that he has lost some of the freedom to pursue these activities as a result of his family life, and this is occasionally a problem for him. His partner holds a different view of the organization of the family's leisure time. Jane wants to spend more time as a family unit so that everyone can take part in activities together. She comments on the way Peter prioritizes his personal interests: 'Conflicts occur when he is busy a lot with his own things.' 
The sporting events Peter follows are a particular source of conflict between them. This conflict tends to escalate during the holiday season when he is watching games and Jane wants the family to be together. Problems that arose during a summer holiday that coincided with the football season are one example of such a conflict. Because his interests are bound to outside events, the challenges around the organization of the family's leisure time increase.

The conflicts associated with the way Peter gives priority to his interests can be understood by the emphasis he puts on independence as being more important for him than for his partner. He explains:

My wife has higher expectations of everyday life than I can fulfil. To be on one's own is more important for me than it is for her. But I do get permission once in a while. I feel some pressure to participate in family activities and I do my best.

The importance he ascribes to independence can be linked to his desire to both engage in his own interests and to withdraw in order to put distance between himself and the perceived expectations of his partner. For Peter family time is associated with duty, while being on his own is associated with pleasure. For Jane the conflicts related to independence are grounded in her perception that Peter prioritizes leisure time on his own terms and shows too little consideration for her and her wish for more time together. She claims that by putting his own recreational interests first, Peter avoids participating in family activities. So, it is not time-bound and time-consuming interests, per se, that lead to conflicts for this couple, but the prioritization of one person's interests with too little consideration for the other's. His insistence on the need for time of his own also communicates a wish to withdraw and distance himself from her demands.

Peter and Jane have different values concerning the organization of their leisure time. But the conflicts between them are, according to their comments, due to the way they communicate about the issue of separate-versus-shared time. Jane especially emphasizes her partner's lack of consideration for her interests. This pattern is in accordance with studies which emphasize selfrealization as more self-evident for men than for women (Magnusson, 2008) and the finding that men more often than women make decisions on their own terms at the expense of maintaining togetherness (Røthing, 2004). Thus, the different values held by the members of this couple reinforce the conflicts they experience around the organization of leisure time.

The disagreements over Peter's leisure time lead to frequent confrontations. In these situations Jane tries to keep calm and to find solutions they can both accept. Hence, the responsibility for coping with challenges is left to Jane. Peter comments on her initiative towards solving challenging issues: 
It is usually Jane who talks about our problems and suggests how we can solve them and put them behind us. It is OK, but it can take some time. Problems are seldom hidden, she does not allow that. If it had been up to me, I would prefer to hide the problems, I'm good at denial.

The pattern of conflicting independence accords with Beck and BeckGernsheim's (1995) assertion that freedom for one partner represents renunciation of freedom for the other. When the man insists on being free to decide how to spend his leisure time, his partner's freedom is restricted; time together is an increasingly elusive option.

\section{Collaborative independence}

The case of Stephen and Ann illustrates the pattern of collaborative independence. Stephen, like many of the other men in this study, favours typically male interests such as attending or participating in sporting activities and watching sports on TV. It is also important to him to have the opportunity to meet friends and colleagues after work once in a while. He explains what independence means to him:

I believe it is essential to have activities outside of the relationship. And it feels great to be alone once in a while. But I try to prioritize my time so that we all can spend leisure time together.

Ann appreciates that he is clear about his priorities, which include her and the rest of the family: 'I enjoy when we take the children with us in the forest on Sundays. We have picnics in the summer, and go skiing in the winter'.

In this couple, both partners want time for individual interests and both give priority to joint activities. Challenges concerning the organization of leisure time are associated with Stephen's interests, as they are more timeconsuming and time-bound than Ann's. This is especially evident when he is watching sporting events. Ann, however, expresses an understanding of the situation: 'My impression is that the closest football match is always the one that is most important. He has to watch the matches when they take place.' She describes her own interests and discusses how she organizes them: 'My interests are more flexible than his. I run regularly and I always find some time to meet my friends.'

Ann also emphasizes the importance of having some time for herself. Ann and Stephen had different values concerning the organization of their leisure time at the beginning of their relationship, but they gradually reached a consensus. At the time of the interview, their negotiations were taking into account that they both have separate interests and want time for family activities. Neither of them mentions feeling that their partner expects them to contribute more to the 
family than they already do. Rather, both base their decisions about the organization of leisure time on a consideration of each other's interests. This type of mutual respect is the basis for denoting this process as collaborative independence.

The relationship between Stephen and Ann is characterized by their mutual understanding of the interests and priorities that are important for the partner, an understanding they have reached over the time. This mutual understanding implies an appreciation of the partner. Stephen and Ann also share the responsibility for dealing with challenges in the relationship. Both of them emphasize the importance of bringing up controversial issues at an early stage. Stephen describes his role in these situations: 'I take the initiative to negotiate issues which are necessary in order to achieve a balance in the relationship which both of us can accept.'

Negotiations between partners, which represent the essential aspect of collaborative independence, do not support Beck and Beck-Gernsheim's hypothesis about the paradox of freedom, wherein the freedom for one partner represents the renunciation of freedom for the other. Collaborative independence implies that the priorities that one person sets can also take into consideration what the other person wants. To achieve this, neither of the two partners must see the partner's need for a space of one's own as entailing a withdrawal or distancing from the other or from the family. Independence can, in this context, be interpreted as a way of revitalizing oneself, which, in turn, may contribute to maintaining and even strengthening the couple relationship.

\section{Three models of commitment}

The dimensions of commitment and independence and men's responses to challenges in the relationship combine in patterns which represent the basis for three models. The patterns are indicative of different approaches to the issue of emotional responsibility among men from fairly similar social backgrounds.

The model of shared responsibility is characterized by the man's sharing of the responsibility for maintaining the emotional bond with the partner. The model implies responsive commitment in terms of the man's contributions. The man's contributions - whether verbal or task-related - communicate emotional involvement, and the female partner gives corresponding feedback. The interaction between the partners is characterized by the development of a mutual understanding of the other partner's point of view. The model also implies collaborative independence in terms of the man's contributions. The implication of collaborative independence is that the priorities set by one person also take into consideration what the other person wants. Furthermore, both partners give investments in the relationship high priority and share the 
responsibility for coping with challenges. Four couples represent the basis for this model, two express communicative commitment, and two express taskoriented commitment.

The model of gendered responsibility reflects a more traditional division of emotional labour. The basis for this model is that the woman takes the main responsibility for the emotional bond. The interaction is characterized by nonresponsive commitment, which implies that the man contributes to the relationship in ways which leave the partner wanting confirmation and appreciation. The model also implies conflicting independence. The conflicting interaction these couples express is associated with the man's prioritization of his own time. The man expresses little understanding of his partner's needs and wishes, and he does not share the responsibility for relationship challenges with his partner. Four couples represent the basis for this model.

The data also support a third model, the model of partial responsibility. This model represents a position somewhere between the other two. It is characterized by the man's responsibility for collaborative practices in relation to the organization of the couple's leisure time, but not concerning expressions of commitment. The man's prioritization of his own time takes into consideration what his partner wants. However, the man's communication of emotional involvement offers little consideration for the female partner's need for confirmation and appreciation. The implication of non-responsive commitment is that the woman has the main responsibility for challenges in the relationship. While the man acknowledges the importance of investing in the relationship, he shows no initiative to act on the challenges the couple is facing. Two couples represent the basis for this model.

The fourth possible combination of commitment and independence, that of responsive commitment and conflicting independence, has no empirical basis in our data. This combination, which also represents a form of partial responsibility, may apply to couples whose relationships are in earlier phases, where the communication of emotional involvement can be characterized by responsive commitment, but the parties have not yet developed collaborative practices. It may be that the appreciation of the partner associated with responsive commitment represents the basis for developing collaboration in a longer perspective.

\section{Discussion}

Our analyses suggest a marked diversity in present-day Norway in the approaches to emotional responsibility taken by middle-class men, a segment of the population that identifies with dominant gender-equality discourses. In respect of gender equality, the model of shared emotional responsibility represents an egalitarian pattern, while the model of gendered emotional 
responsibility represents a traditional pattern. The third model of partial emotional responsibility can be interpreted in different ways. Our interpretation is that it points towards a more non-traditional pattern of emotional responsibility than the model of gendered responsibility does. The diversity we have described may indicate that heterosexual middle-class couples are in a phase of transition between traditional and egalitarian practices.

The link between middle-class culture and the pattern of shared emotional responsibility is supported by research on other aspects of couple relationships and family life among the middle class, as well as research on middle-class working life and lifestyles. For example, research on attitudes towards equality and sharing practices concerning household duties indicates that equality both in attitudes and concerning sharing of household duties is more widespread among men and women with higher education compared with men and women with less education (Kjeldstad \& Lyngstad, 2010).

Drawing on empirical data on Norwegian middle-class couples, Aarseth (2009) finds an emerging pattern of degendered division of labour. She attributes this change to a re-articulation, among middle-class men, of the emotional meanings entrenched in the practice of homemaking, transcending the traditional division between 'duty' and 'fun'. Qualitative studies on parenthood in Norway also find that middle-class couples share the responsibility for child care more equally than working-class couples do (Stefansen \& Farstad, 2010). Men's emotional responsibilities in couple relationships can also be associated with a new cultural emphasis on emotional competence, which applies especially to the middle class. Women have traditionally been experts on relational competence (Illouz, 1997; Kimmel, 2004) and this has lead to separate emotional cultures for men and women (Duncombe \& Marsden, 1999). The cultural emphasis on the importance of relational competence applies to both men and women in the working life associated with the 'new' middle-class. The demand for emotional competence in the working culture is evident in the market for courses on leadership training and conflict management, coaching services, and seminars on collaboration.

This cultural demand for emotional competence applies to the private sphere as well, and is reflected in the increasing availability of courses, books, and journal articles regarding how to manage the couple relationship. This cultural emphasis on relational competence implies that such competence represents a goal for men as well as for women - at least in the middle class. This change may lead to a transcendence of the traditional pattern of separate emotional cultures, in our study conceptualized as the model of shared responsibility. 


\section{Conclusion}

In our sample of Norwegian middle-class couples, the dimensions of commitment and independence - key aspects of couple relationships combine into three distinct models: shared responsibility, gendered responsibility, and partial responsibility. Hence, a key finding is that, among men from similar social backgrounds, contributions to the emotional bonds in lasting couple relationships vary. However, the models of shared and partial responsibility are indicative of a change towards more egalitarian patterns in the division of emotional work in heterosexual couples - at least among the middle class.

\section{References}

Asplund, J. (1987). Det sociala livets elmentära former. Gøteborg: Bokförlaget Korpen.

Beck, U., \& Beck-Gernsheim, E. (1995). The Normal Chaos of Love. Cambridge, UK: Blackwell.

Cancian, F. M. (1986). The Feminization of Love. Signs, 11, 692-709.

Connell, R. W., \& Messerschmidt, J. W. (2005). Hegemonic masculinity: Rethinking the concept. Gender \& Society, 19(6), 829-859.

Dempsey, K. (2002). Who gets the best deal from marriage: women or men? Journal of Sociology, 38(2), 91-110.

Duncombe, J., \& Marsden, D. (1998). "Stepford wives" and "hollow men"? Doing emotion work, doing gender and "authenticity" in intimate heterosexual relationships. In G. Bendelow \& S. J. Williams (Eds), Emotions in Social Life. Critical Themes and Contemporary Issues (pp. 211-227). London: Routledge.

Duncombe, J., \& Marsden, D. (1999). Love and intimacy: The gender division of emotion and "emotion work": A neglected aspect of sociological discussion and heterosexual relationships. In G. Allan (Ed.), The Sociology of the Family (pp. 91-110). Oxford: Blackwell Publishers.

Ellingsæter, A. L. (2011). Symmetrisk foreldreskap: politiske forhindringer. Tidsskrift for samfunnsforskning, 52(1), 3-32.

Giddens, A. (1992). The Transformation of Intimacy: Sexuality, Love and Eroticism in Modern Societies. Cambridge: Polity Press.

Gornick, J. C., \& Meyers, M. K. (2009). Institutions that support gender equality in parenthood and employment. In J. C. Gornick \& M. K. Meyers (Eds.), Gender equality: Transforming family divisions of labor. (pp. 3-66). London: Verso.

Hochschild, A. R. (2003). The Commercialization of Intimate Life. Notes from Home and Work. (Los Angeles: University of California Press. 
Holmberg, C. (1995). Det kallas kärlek. Om kvinnligt och manligt. Maktförhållandet i parrelationer. Gothenburg: Anamma Förlag.

Holmes, M. (2004). An equal distance? Individualization, gender and intimacy in distance relationships. The Sociological Review, 52(2), 180-200.

Holter, Ø. G., Svare, H., \& Egeland, C. (2008) Likestilling og livskvalitet 2007. Oslo: Arbeidsforskningsinstituttet.

Haavind, H. (2000). Analytiske retningslinjer ved empiriske studier av kjønnede betydninger. In H. Haavind (Ed.), Kjønn og fortolkende metode: Metodiske muligheter i kvalitativ forskning (pp. 155-220). Oslo: Gyldendal Akademisk.

Illouz, E. (1997). Consuming the Romantic Utopia. Love and the Cultural Contradictions of Capitalism. Los Angeles: University of California Press.

Jamieson, L. (1998). Intimacy. Personal Relationships in Modern Societies. Cambridge: Polity Press.

Jamieson, L. (1999). Intimacy transformed? A critical look at the "pure relationship". Sociology, 33(3), 477-494.

Jónasdóttir, A. G. (1991). Love Power and Political Interests. Towards a Theory of Patriarchy in Contemporary Western Societies. Örebro: University of Örebro.

Kimmel, M. S. (2004). The Gendered Society. Oxford: Oxford University Press.

Kjeldstad, R., \& Lyngstad, J. (2010). Utradisjonell likestilling? Analyser av undersøkelsen Livsløp, generasjon og kjønn. Oslo: Statistisk sentralbyrå.

Lister R. (2009). A Nordic Nirvana? Gender, Citizenship, and Social Justice in the Nordic Welfare States. Social Politics, 16(2), 242-278.

Magnusson, E. (2006). Hon, han och hemmet: Genuspsykolgiska perspektiv på vardagslivet i nordiska barnfamiljer. Stockholm: Natur \& Kultur.

Magnusson, E. (2008). The rhetoric of inequality: Nordic women and men argue against sharing house-work. NORA-Nordic Journal of Women's Studies,16, 7995.

Parker, A. (1996). Sporting masculinities: Gender relations and the body. In M. Mac an Ghaill (Ed.), Understanding masculinities (pp. 126-39). Buckingham: Open University Press.

Rauer, A. J., \& Volling, B. L. (2005). The role of husbands' and wives' emotional expressivity in the marital relationship. Sex Roles, 52, 577-87.

Røthing, Å. (2004). Parforhold. Idealer, forhandlinger, strategier. Oslo: Gyldendal Norsk Forlag.

Seidler, V. J. (1998.) Masculinity, violence and emotional life. In G. Bendelow \& S. J. Williams (Eds.), Emotions in social life. Critical themes and contemporary issues (pp. 193-210). London: Routledge. 
Strazdins, L., \& Broom, D. H. (2004). Acts of love (and work). Gender imbalance in emotional work and women's psychological distress. Journal of Family Issues, 25, 356-378.

Stefansen, K. \& Farstad, G.R. (2010). Classed parental practices in a modern welfare state: Caring for the under threes in Norway. Critical Social Policy, 30,(1) 120141.

Thagaard, T. (2005). Følelser og fornuft. Kjærlighetens sosiologi. Oslo: Abstrakt.

Aarseth, H. (2008). Fortellinger om kjønn, makt og kjærlighet. Svar til Hanne Haavind. Tidsskrift for kjønnsforskning, 32, 80-88.

Aarseth, H. (2009). From modernized masculinity to degendered lifestyle projects: Changes in men's narratives on domestic participation 1990-2005. Men and Masculinities, 11, 424-440. 